\title{
Peran Ferritin pada Stroke Iskemik Akut
}

\author{
Lisda Amalia \\ Departemen Neurologi, Fakultas Kedokteran, Universitas Padjadjaran, Bandung, Indonesia
}

\begin{abstract}
Abstrak
Stroke merupakan defisit neurologis yang terjadi karena jejas fokal akut pada sistem saraf pusat yang semata-mata terjadi karena gangguan vaskuler, termasuk infark serebri maupun perdarahan. Ferritin adalah protein intraselular dan ekstraselular penyimpan zat besi yang penting bagi homeostasis besi dalam tubuh. Ferritin diekspresikan di mikroglia dan makrofag, namun ada juga di dalam neuron. Pada saat terjadi kerusakan sel akibat stroke iskemik, ferritin akan keluar dari sel dan masuk ke dalam serum. Keadaan hipoksia-iskemia pada stroke menginduksi ekspresi dari ferritin pada oligodendrosit dan mikroglia. Saat terjadi stres oksidatif, pembentukan ferritin akan meningkat. Fungsi ferritin pada saat stres oksidatif terjadi, masih kontroversial. Ferritin dalam kondisi tersebut dapat berperan sebagai pembersih (scavenger) dan sebagai donor untuk ion besi bebas. Pasien stroke iskemik dengan lesi yang lebih besar dan defisit neurologis yang lebih berat menunjukkan peningkatan kadar serum ferritin yang lebih tinggi dan kecenderungan terjadinya komplikasi trasformasi perdarahan akan semakin tinggi pula.
\end{abstract}

Kata kunci: ferritin, luaran klinis, stroke iskemik akut

JNI 2021;10 (2): 127-132

\section{Role Of Ferritin in Acute Ischemic Stroke: A Literature Review}

\begin{abstract}
Stroke is a neurological deficit that occurs due to acute focal injury to the central nervous system that occurs solely due to vascular disorders, including cerebral infarction or bleeding. Ferritin is an intracellular and extracellular iron storage protein which is essential for iron homeostasis in the body. Ferritin is expressed in microglia and macrophages, and also in neurons. If there is cell damage due to ischemic stroke, ferritin will leave the cells and enter the serum. The hypoxia-ischemic state in stroke induces the expression of ferritin in oligodendrocytes and microglia. When there is oxidative stress, ferritin formation will increase. The function of ferritin in times of oxidative stress is still controversial. Ferritin in this condition can act as a scavenger and as a donor for free iron ions. Ischemic stroke patients with larger lesions and more severe neurological deficits showed higher serum ferritin levels and a higher likelihood of complications of bleeding transformation.
\end{abstract}

Key words: ferritin, ischemic stroke, outcome

JNI 2021;10 (2): 127-132

This article is licensed under

Creative Commons Attribution-NonCommercial-ShareAlike 4.0 International License.

CLisda Amalia

(2021) under the CC-BY-NC-SA license 


\section{Pendahuluan}

Stroke adalah penyebab utama terbesar dari kecacatan pada orang dewasa. Stroke merupakan masalah kesehatan yang besar di Indonesia. Berdasarkan hasil riset kesehatan dasar (RISKESDAS) yang dilakukan oleh Kementrian Kesehatan Republik Indonesia tahun 2013, prevalensi stroke di Indonesia yang terdiagnosis sekitar 7 per mil sedangkan yang bergejala sekitar 12,1 per mil. ${ }^{1}$ Stroke merupakan defisit neurologis yang terjadi karena jejas fokal akut pada sistem saraf pusat yang semata-mata terjadi karena gangguan vaskuler, termasuk infark serebri maupun perdarahan. Definisi stroke menurut World Health Organization (WHO) adalah tanda klinis dari gangguan fungsi serebral baik fokal maupun global yang berlangsung lebih dari 24 jam atau menyebabkan kematian, sematamata disebabkan oleh gangguan vaskuler. ${ }^{2}$

\section{Patofisiologi Stroke Iskemik}

Terdapat tiga mekanisme stroke iskemik, yaitu trombosis, emboli, dan menurunnya perfusi sistemik (gambar 1). Trombosis adalah obstruksi dari aliran darah karena oklusi pada satu atau lebih pembuluh darah oleh plak. Plak yang besar dapat menutup lumen pembuluh darah. Emboli merupakan material yang terbentuk di suatu tempat di sistem vaskular dan terlepas ke arteri

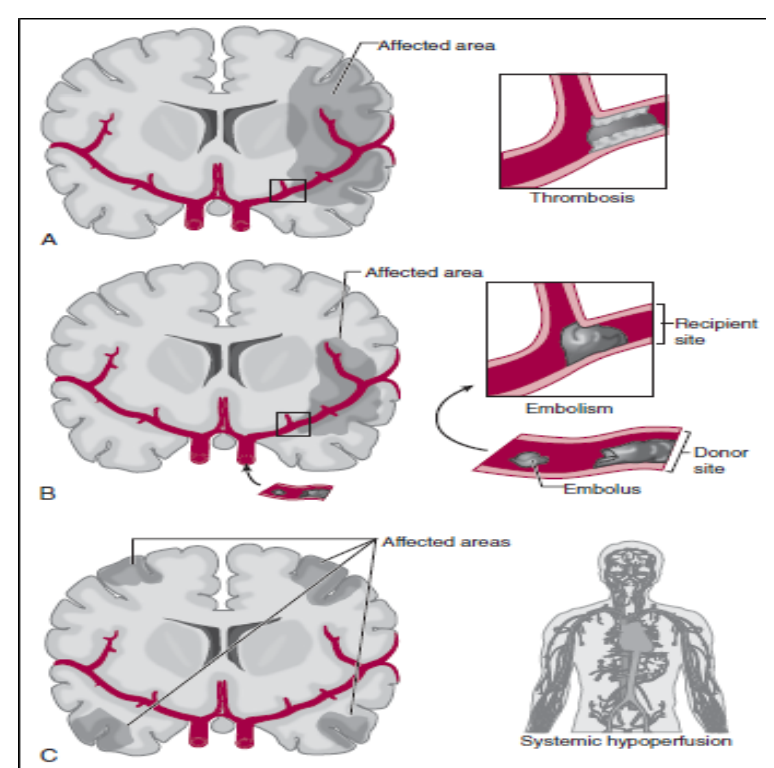

Gambar 1. Ilustrasi Tiga Penyebab Iskemia Otak ${ }^{3}$ sehingga menyebabkan blokade aliran darah. Pada penurunan perfusi sistemik, aliran darah ke otak juga menurun. Penurunan perfusi iskemik biasanya terjadi karena kegagalan pompa jantung dan hipotensi sistemik. ${ }^{3}$ Pada awal sumbatan terjadi, daerah penumbra biasanya meliputi sepertiga bahkan setengah dari total volume lesi. Pada daerah penumbra ini, mekanisme kematian sel secara aktif terjadi (gambar 2). ${ }^{1}$

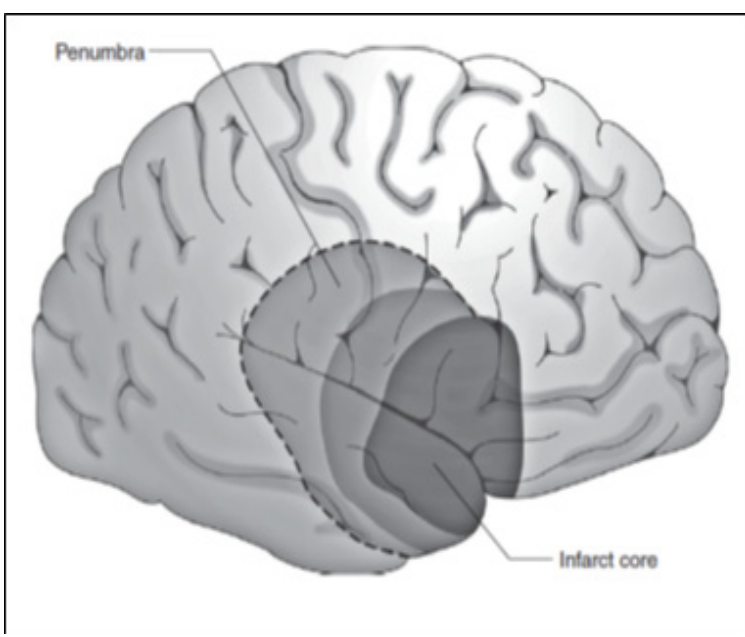

Gambar 2. Pusat infark dan penumbra (disadur dari Caplan's stroke) ${ }^{1}$

Homeostasis Zat Besi dan Fungsi Normal Otak Metabolisme zat besi memegang peranan dalam menjaga fungsi normal otak karena zat besi adalah logam yang paling banyak ditemukan di otak. ${ }^{5,6}$ Pembentukan beberapa neurotransmitter bergantung pada zat besi. ${ }^{4,7}$ Pada kondisi fisiologis, zat besi selalu berikatan dengan protein pembawa, kebanyakan dalam bentuk hemoglobin dan protein heme pembawa oksigen. Sedangkan, zat besi non-heme lainnya akan berikatan dengan transferrin dan ferritin. Sebanyak kurang lebih sepertiga hingga tiga per empat zat besi dalam otak disimpan dalam bentuk ferritin, terutama di sel-sel glia (gambar 3). ${ }^{5,7}$

Pada keadaan normal, mekanisme penghantaran zat besi dari luar sel ke dalam sel diatur oleh sistem transferrin-reseptor transferrin. Transferrin inilah yang akan mengambil zat besi $(\mathrm{Fe} 3+)$ di ekstraselular lalu berikatan dengan reseptor transferrin di membran sel hingga terjadi 


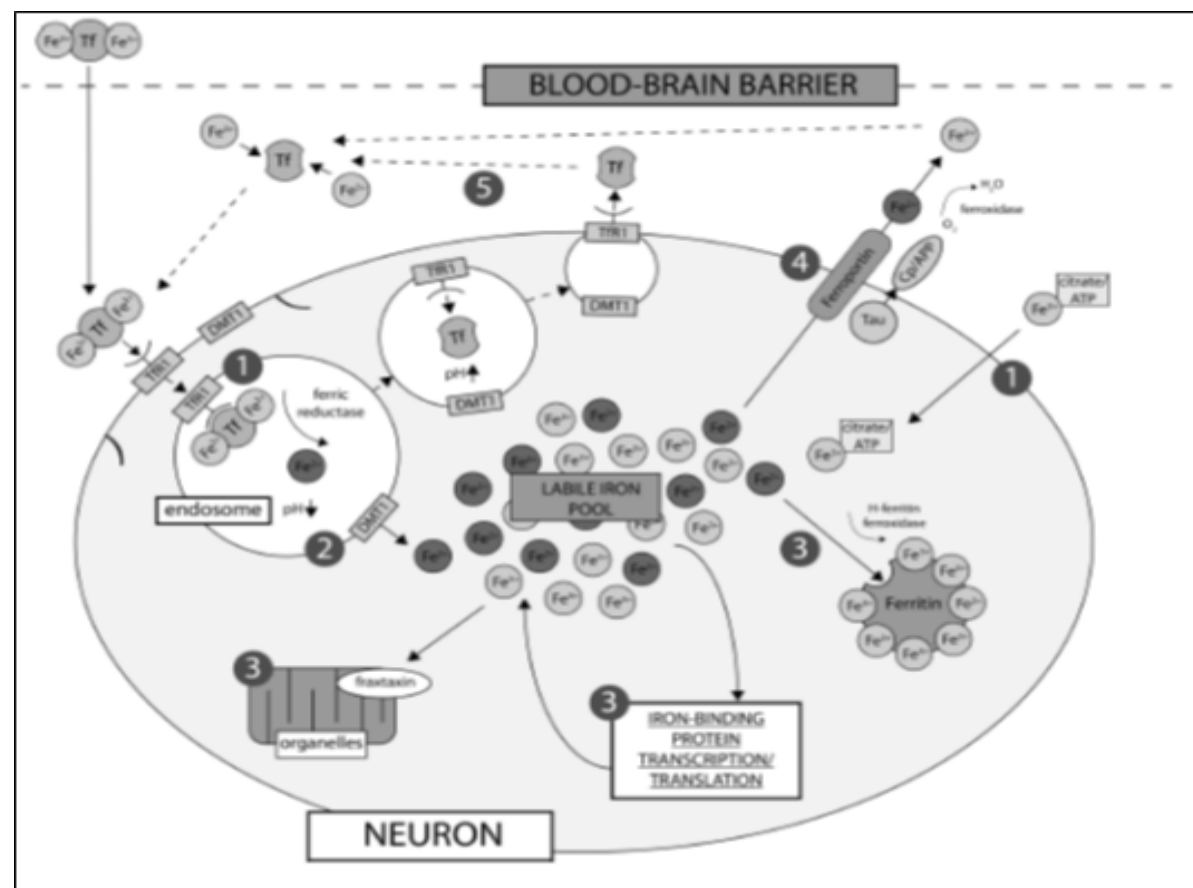

Gambar 3. Pengambilan dan Pengeluaran Ion Besi dalam Sel Saraf.,

endositosis. Setelah terjadi endositosis, ion Fe3+ diubah menjadi $\mathrm{Fe} 2+$ dan dikeluakan dariendosom ke sitoplasma oleh Divalent Metal Transporter 1 (DMT1). Ion besi di sitoplasma ini bersifat labil dan berada di dalam lisosom. Ion tersebut berada dalam keadaan yang seimbang dengan ferritin. ${ }^{5}$ Kebutuhan oksigen otak meningkat saat terjadi iskemia sehingga terjadi peningkatan akan kebutuhan transpor zat besi dan penggunaannya di area tertentu. Sumber dan bentuk pasti dari ion besi yang dikeluarkan saat iskemia serebri belum sepenuhnya diidentifikasi. Ada beberapa kemungkinan gangguan keseimbangan besi di dalam otak pasca stroke iskemik, yaitu antara lain gangguan pada transferrin, ferritin, atau ion besi transisional. ${ }^{7}$ Walaupun mekanismenya belum jelas, namun diperkirakan bahwa aktivitas dekomposisi dari protein yang mengandung besi dalam lisosom berperan dalam pengeluaran ion besi. Zat besi dapat terlepas dari ikatannya dengan

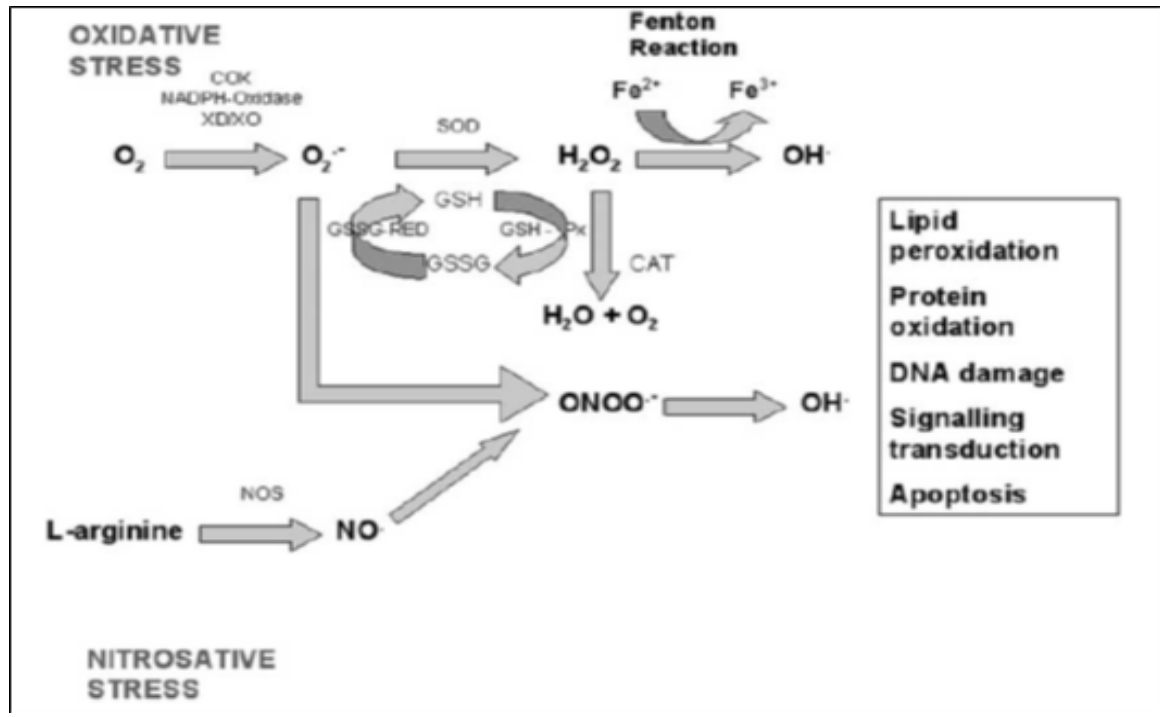

Gambar 4. Produksi Stres Oksidatif/nitrosatif dan Efeknya ${ }^{7-10}$ 
protein penyimpanan di otak apabila terjadi kondisi hipoksia. ${ }^{6}$ Ion besi yang bebas inilah yang akan memperoksidasi lemak di membran sel dan memprovokasi terjadinya respon inflamasi serta eksitotoksisitas glutamat (gambar 4). ${ }^{7-10}$

\section{Ferritin pada Stroke Iskemik}

\section{Ferritin sebagai scavenger}

Pada penyakit serebrovaskuler, adanya radikal oksigen superoksida meningkatkan jumlah besi dalam sitosol dengan jalan melepaskan besi tersebut dari ferritin. ${ }^{4,7,8,11-18}$ Keadaan hipoksiaiskemia menginduksi ekspresi dari ferritin pada oligodendrosit dan mikroglia. ${ }^{19}$ Saat terjadi stres oksidatif, pembentukan ferritin akan meningkat (gambar 5). ${ }^{4}$ Kebanyakan stimulus yang berhubungan dengan inflamasi akan menyebabkan peningkatan produksi ferritin. Hal ini berhubungan dengan tingginya kadar oksida nitrat (NO) yang akan mendorong pembentukan ferritin secara tidak langsung. ${ }^{11-13}$ Fungsi ferritin pada saat stres oksidatif terjadi, masih kontroversial. Ferritin dalam kondisi tersebut dapat berperan sebagai pembersih (scavenger) dan sebagai donor untuk ion besi bebas. ${ }^{4}$
Ferritin sebagai Prediktor Luaran Klinis

Sebuah studi menunjukkan adanya peningkatan serum ferritin pada tikus 1 hari setelah iskemia. ${ }^{19}$ Pada penelitian tersebut didapatkan bahwa peningkatan serum ferritin sebelum terjadinya iskemia otak tidak berhubungan dengan besarnya infark dan kadar ferritin serum meningkat pada pasien stoke iskemik dalam 24 jam pertama. Kadar serum ferritin yang tinggi saat awal masuk rumah sakit dapat menjadi prediktor terjadinya perburukan, besarnya infark dan terjadinya transformasi atau perdarahan setelah thrombolisis. Penelitian ini juga menunjukkan nilai modified Rankin Scale (mRS) yang lebih buruk pada pasien dengan kadar ferritin tinggi saat masuk rumah sakit. ${ }^{15,19}$ Zat besi dalam otak pada hewan terakumulasi mulai hari pertama dari perdarahan intraserebri dan memuncak di hari ke-3. ${ }^{18,19}$ Kadar ferritin serum dalam 12 jam pertama pasca perdarahan intraserebri dapat menjadi acuan prognosis pasien ke depannya dan kadarnya tetap stabil dalam 72 jam berikutnya. ${ }^{15}$ Kadar ferritin serum juga berhubungan dengan prognosis pada pasien stroke infark dan perdarahan. Beberapa penelitian lain juga menyatakan hal serupa. Pasien dengan

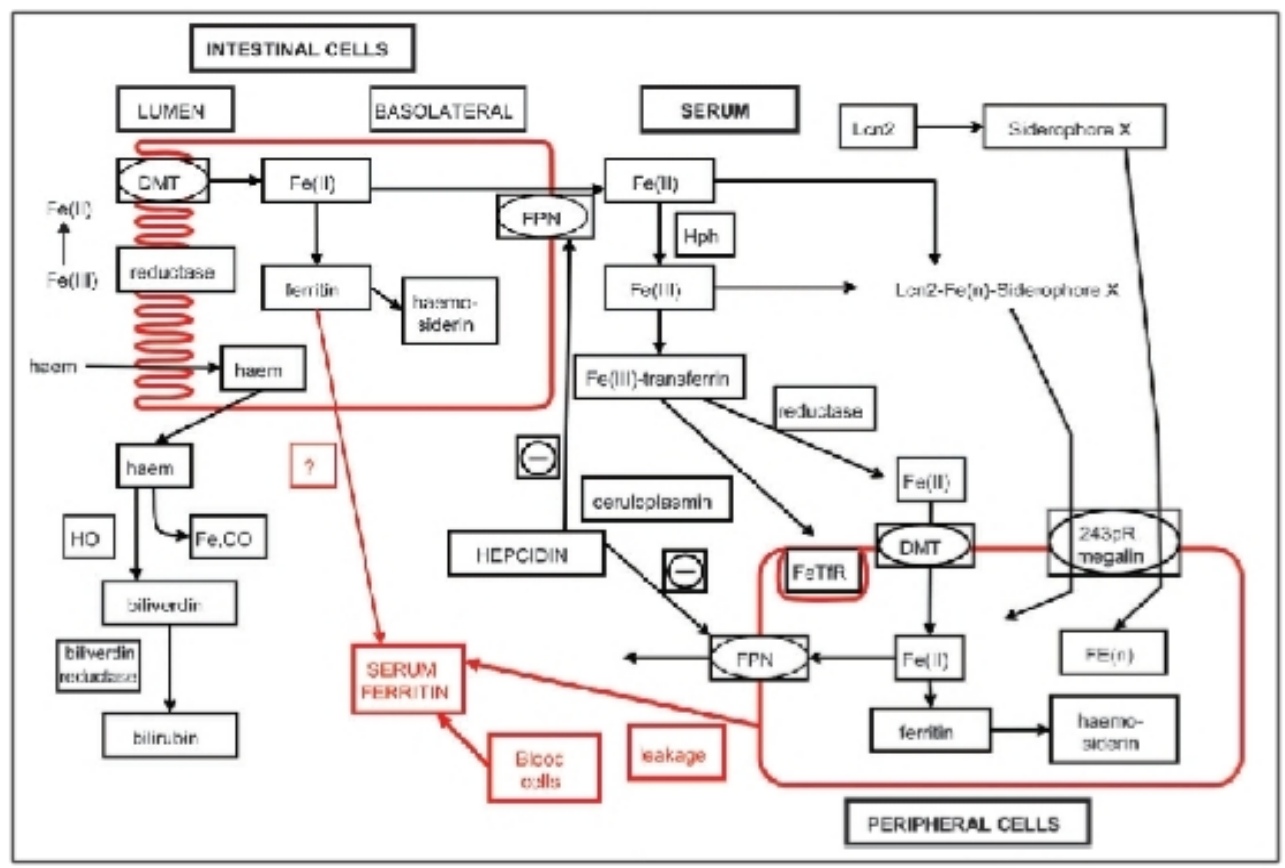

Gambar 5. Ikhtisar dari metabolisme zat besi dan munculnya ferritin dalam serum yang dianggap berasal dari kebocoran dari sel perifer ${ }^{4}$ 
lesi yang lebih besar dan defisit neurologis yang lebih berat menunjukkan peningkatan kadar serum ferritin yang lebih tinggi. ${ }^{15-17}$

\section{Prediktor komplikasi pasca stroke iskemik}

Peningkatan ferritin pada pasien stroke infark berkisar antara $378,4 \pm 51,2$ pada infark luas, $209 \pm 33 .{ }^{9}$ pada infark medium, dan $145,7 \pm 20,8$ pada pasien dengan infark kecil. ${ }^{17}$ Rata-rata pasien infark dengan transformasi hemorrhagik memiliki nilai ferritin serum 198,32 ng/ mL. ${ }^{10}$ Ferritin dalam cairan serebrospinal (CSS) ditemukan meningkat pada pasien yang mengalami gangguan serebrovaskular. Nilai ferritin dalam CSS pada pasien dengan stroke pendarahan lebih tinggi dibandingkan dengan stroke infark. Saat itu muncul spekulasi bahwa peningkatan ferritin pada CSS pasien penderita stroke meningkat karena terlepasnya ferritin dari makrofag. Dari penelitian tersebut dapat dikatakan bahwa peningkatan ferritin pada CSS merefleksikan respon inflamasi yang terjadi saat stroke dan hal ini sesuai dengan semakin luasnya lesi iskemik pasca iskemik terjadi. ${ }^{20}$

\section{Simpulan}

Metabolisme zat besi memegang peranan dalam menjaga fungsi normal otak karena zat besi adalah logam yang paling banyak ditemukan di otak. Pembentukan beberapa neurotransmitter bergantung pada zat besi. Zat besi dapat terlepas dari ikatannya dengan protein penyimpanan di otak apabila terjadi kondisi hipoksia. Keadaan hipoksia-iskemia seperti pada stroke iskemik, akan menginduksi ekspresi dari ferritin pada oligodendrosit dan mikroglia. Saat terjadi stres oksidatif, pembentukan ferritin akan meningkat, semakin tinggi kadar ferritin maka akan semakin berat derajat keparahan stroke sehingga ferritin dapat dijadikan sebagai prediktor luaran klinis stroke iskemik fase akut.

\section{Daftar Pustaka}

1. Caplan LR. Caplan's Stroke: A clinical approach. 4th ed. Philadelphia: Saunders Elsevier; 2009.
2. Carbonell T, Rama R. Iron, Oxidative stress and early neurological deterioration in ischemic stroke. Current Medicinal Chesmistry. 2007;14:857-74.

3. Garton T, Keep RF, Hua Y, Xi G. Brain iron overload following intracranial haemorrhage. Stroke and Vascular Neurology. 2016;1.

4. Sorond FA, Ratan RR. Ironing-out mechanism of neuronal injury under hypoxic-ischemic conditions and potential role of iron chelators as neuroprotective agents. Antioxid Redox Signal. 2000;2:421-36.

5. Selim MH, Ratan RR. The role of iron neurotoxicity in ischemic stroke. Ageing Research Reviews. 2004;3:345-53.

6. Choi KH, Park MS, Kim JT, Nam TS, Choi SM, Kim BC, dkk. The serum ferritin level is an Important predictor of hemorrhagic transformation in acute ischaemic stroke. European Journal of Neurology. 2012;19:570-7.

7. Kell DB, Pretorius E. Serum ferritin is an important inflammatory disease marker, as it is mainly a leakage product from damaged cells. Metallomics. 2014;6:748.

8. Arosio P, Levi S. Ferritin, iron homeostasis, and oxidative damage. Free Radical Biology and Medicine. 2002;33:457-63.

9. Davalos A, Fernandes-Real JM, Ricart W, Soler S, Molins A, Planas E, dkk. Iron-related damage in acute ischemic stroke. Stroke. 1994;25:1543-6.

10. Charles Moore J, Ormseth M, Fuchs H. Causes and significance of markedly elevated serum ferritin levels in an academic medical center. J Clin Rheumatol. 2013;19:324-8.

11. Lipscomb D, Gorman L, Traystman R, Hurn P. Low molecular weight iron in cerebral ischemic acidosis in vivo. Stroke. 1998;29:487-92. 
12. Reif DW. Ferritin as a source of iron for oxidative damage. Free Radic Biol Med. 1992;12:417-27.

13. Bishop GM, Robinson SR. Quantitative analysis of cell death and ferritin expression in response to cortical iron: implications for hypoxia-ischemia and stroke. Brain Research. 2001;907(175-187).

14. Millerot E, Prigent-Tessier AS, Bertrand NM, Faure PJ-C, Mossiat CM, Giroud ME, dkk. Serum ferritin in stroke: a marker of increased body iron stores or stroke severity? journal of cerebral blood flow \& metabolism. 2005;25:1386-93.

15. Millan M, Sobrino T, Castellanos M, Nombela F, Arenillas JF, Riva E, dkk. Increased body iron stores are associated with poor outcome after thrombolytic treatment in acute stroke. stroke. 2007;38:90-5.

16. Ossa NPdl, Sobrino T, Silva Y, Blanco M, Millan M, Gomis M, dkk. Iron-related brain damage in patients with intracerebral hemorrhage. Stroke. 2010;41:810-3.
17. Hallgren R, Terent A, Wide L, Bergstrom K, Birgegard G. Cerebrospinal fluid ferritin in patients with cerebral infarction or bleeding. Acta neurol scandinav. 1980;61:384-92.

18. Ermodeglu AK, Ozbakir S. Serum ferritin levels and early prognosis of stroke. European Journal of Neurology. 2002;9:633-7.

19. Garcia-Yebenes I, Sobrado M, Moraga A, Zarruk JG, Romera VG, Pradillo JM, dkk. Iron overload, measured as serum ferritin, increases brain damage induced by focal ischemia and early reperfusion. Neurochemistry International. 2012;61(13541369).

20. Chakraborty B, Vishnoi G, Goswami B, Gowda SH, Chowdhury D, Agarwal S. Lipoprotein (a), ferritin, and albumin in acute phase reaction predicts severity and mortality of acute ischemic stroke in north indian patients. Journal of Stroke and Cerebrovascular Disease. 2013;22:e159-e67. 